\title{
Design and control of a DSTATCOM for power quality improvement using cross correlation function approach
}

\author{
Bhim Singh, Sabha Raj Arya* \\ Department of Electrical Engineering, Indian Institute of Technology Delhi, New Delhi-110016, INDIA \\ E-mails: bhimsingh1956@gmail.com, sabharaj1@gmail.com (Corresponding Author*),Tel +91-11-26596225
}

\begin{abstract}
This paper presents the design of a three phase DSTATCOM (Distribution Static Compensator) and its control algorithm based on correlation and cross correlation function approach for power quality improvement under linear/ nonlinear loads in a distribution system. In this approach, an extraction of fundamental active and reactive power components of load currents is based on correlation and cross correlation functions in time domain. For estimation of fundamental active and reactive power components of load currents, a numerical integration is applied in correlation and cross correlation function. The DSTATCOM is modeled under linear and nonlinear loads and its performance is simulated in the MATLAB environment using SIMULINK and Sim Power System (SPS) toolboxes. The performance of DSTATCOM is found satisfactory under time varying and unbalanced loads.
\end{abstract}

Keywords: Correlation and cross-correlation coefficients, DSTATCOM, Power factor correction, Zero voltage regulation.

DOI: http://dx.doi.org/10.4314/ijest.v4i1.9S

\section{Introduction}

Power quality in distribution systems affects all the connected electrical and electronics equipments. It is a measure of deviations in voltage, current, frequency of a particular system and associated components (Devaraju et al, 2010; Fuchs and Mausoum, 2008). In recent years, use of power converters in adjustable speed drives, power supplies etc. is continuously increasing. These equipment draw harmonics currents from AC mains and increase the supply demands (Singh, 2009). These loads can be grouped as linear (lagging power factor loads), nonlinear (current or voltage source type of harmonic generating loads), unbalanced and mixed types of loads. Some of power quality problems associated with these loads include harmonics, high reactive power burden, load unbalancing, voltage variation etc. A survey on power quality problems is discussed for classification, suitable corrective and preventive actions to identify these problems (Saxena et al, 2010). A variety of custom power devices are developed and successfully implemented to compensate various power quality problems in a distribution system. These custom power devices are classified as the DSTATCOM (Distribution Static Compensator), DVR (Dynamic Voltage Restorer) and UPQC (Unified Power Quality Conditioner). The DSTATCOM is a shunt-connected device, which can mitigate the current related power quality problems. The power quality at the PCC is governed by standards such as IEEE-519-1992, IEEE-1531-2003 and IEC- 61000, IECSC77A etc (Ghosh and Ledwich, 2009; Munoz, 2007; Sankaran, 2001).

The effectiveness of DSTATCOM depends upon the used control algorithm for generating the switching signals for the voltage source converter and value of interfacing inductors. For the control of DSTATCOM, many control algorithms are reported in the literature based on the instantaneous reactive power theory, deadbeat or predictive control (Fuchs and Mausoum, 2008), instantaneous symmetrical component theory (Ghosh and Ledwich, 2009), nonlinear control technique (Rahmani et al, 2010), modified power balance theory( Singh and Kumar, 2010), enhanced phase locked loop technique (Sharma and Singh, 2011), addaline control technique, synchronous reference frame control technique (Singh and Solanki, 2009), ANN and fuzzy based controller, SVM based controller (Teke et al, 2011), correlation and cross-correlation coefficients based control algorithm (Tanaka 
et al, 2007) etc. Other techniques applied in active filters are based on Hilbert transform (Wetula, 2008), soft phase locked loop (Wu et al, 2007) and novel hysteresis current controller (Zeng et al, 2010) etc. The control algorithm based on cross correlation function approach has been reported for single phase AC system (Tanaka et al, 2007). In this paper, this control algorithm based on the correlation and cross correlation function approach is used in a three phase distribution system for compensation of reactive current, harmonics current and load balancing in PFC and ZVR modes of operation of DSTATCOM.

\section{Characteristics and Design of DSTATCOM}

A DSTATCOM is a device which is used in an AC distribution system where, harmonic current mitigation, reactive current compensation and load balancing are necessary. The building block of a DSTATCOM is a voltage source converter (VSC) consisting of self commutating semiconductor valves and a capacitor on the DC bus (Singh et al, 2008). The device is shunt connected to the power distribution network through a coupling inductance that is usually realized by the transformer leakage reactance. In general, the DSTATCOM can provide power factor correction, harmonics compensation and load balancing. The major advantages of DSTATCOM compared with a conventional static VAR compensator (SVC) include the ability to generate the rated current at virtually any network voltage, better dynamic response and the use of a relatively small capacitor on the DC bus. The size of the capacitor does not play an important role in steady-state reactive power generation, which results in a significant reduction of the overall compensator size and cost (Ghosh et al, 2002; Padiyar, 2008).

Fig. 1 shows the schematic diagram of a DSTATCOM connected to a three phase AC mains feeding three phase loads. Three phase loads may be a lagging power factor load or an unbalanced load or non-linear loads or mixed of these loads. For reducing ripple in compensating currents, interfacing inductors $\left(\mathrm{L}_{\mathrm{f}}\right)$ are used at $\mathrm{AC}$ side of the voltage source converter (VSC). A small series connected capacitor $\left(C_{f}\right)$ and resistor $\left(R_{f}\right)$ represent the ripple filter installed at PCC in parallel with the loads and the compensator to filter the high frequency switching noise of the voltage at PCC. The harmonics/reactive currents $\left(\mathrm{i}_{\text {Cabc }}\right)$ are injected by the DSTATCOM to cancel the harmonics /reactive power component of the load currents so that the source currents are harmonic free (reduction in harmonics) and load reactive power is also compensated. The rating of the switches is based on the voltage and current rating of the required compensation. For considered load of 35kVA, compensator data are given in Appendix, the rating of the VSC for reactive power compensation/harmonics elimination is found to be $25 \mathrm{kVA}$ (15\% more reactive current from rated value). The selection of the DC bus voltage, DC bus capacitor, AC inductors and the ripple filter of DSTATCOM are given as,

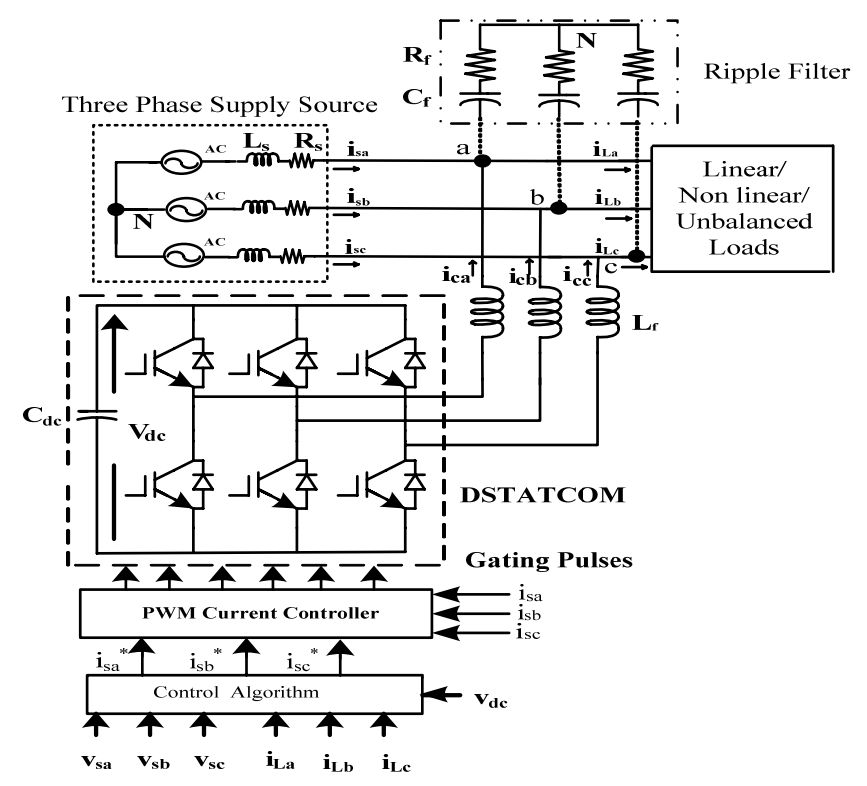

Figure 1. Schematic diagram of DSTATCOM

\subsection{Bus Voltage}

The value of DC bus voltage $\left(\mathrm{V}_{\mathrm{dc}}\right)$ depends on the $\mathrm{PCC}$ voltage and its must be greater than amplitude of the AC mains voltage for successful PWM control of VSC of DSTATCOM. For a three-phase VSC, the DC bus voltage is defined as,

$\mathrm{V}_{\mathrm{dc}}=2 \sqrt{ } 2 \mathrm{~V}_{\mathrm{LL}} /(\sqrt{ } 3 \mathrm{~m})$ 
where, $\mathrm{m}$ is the modulation index and is considered as 1 and $\mathrm{V}_{\mathrm{LL}}$ is the AC line output voltage of DSTATCOM. Thus $\mathrm{V}_{\mathrm{dc}}$ is obtained as $677.69 \mathrm{~V}$ for $\mathrm{V}_{\mathrm{LL}}$ of $415 \mathrm{~V}$ using Eq. (1) and it is selected as $700 \mathrm{~V}$.

2.2 DC Bus Capacitor

The design of the DC bus capacitor is governed by the depression in the DC bus voltage upon the application of the loads and rise in the DC bus voltage on removal of the loads. Using the principle of energy conservation, the equation governing $\mathrm{C}_{\mathrm{dc}}$ is as,

$0.5 \mathrm{C}_{\mathrm{dc}}\left\{\left(\mathrm{V}_{\mathrm{dc}}{ }^{2}\right)-\left(\mathrm{V}_{\mathrm{dcl}}{ }^{2}\right)\right\}=\mathrm{k}\left\{3 \mathrm{~V}_{\mathrm{ph}}(\mathrm{a} \mathrm{I}) \mathrm{t}\right\}$

where, $\mathrm{V}_{\mathrm{dc}}$ is the nominal DC voltage and $\mathrm{V}_{\mathrm{dc}}$ is the minimum voltage level of DC bus, "a" is the over loading factor, $\mathrm{V}_{\mathrm{ph}}$ is the phase voltage, $\mathrm{I}$ is the phase current of the VSC and $\mathrm{t}$ is time for which DC bus voltage is to be recovered.

Considering, $\mathrm{V}_{\mathrm{dc}}=700 \mathrm{~V}, \mathrm{~V}_{\mathrm{dcl}}=677.69 \mathrm{~V}, \mathrm{~V}_{\mathrm{ph}}=240 \mathrm{~V}, \mathrm{I}=38.95 \mathrm{~A}, \mathrm{t}=0.04 \mathrm{~s}, \mathrm{a}=1.2$, and value of $\mathrm{k}$ factor is varying between 0.05 to 0.15 . Using Eq. (2), the calculated value of $\mathrm{C}_{\mathrm{dc}}$ is found to be $8822.33 .69 \mu \mathrm{F}$ and it is selected as $10000 \mu \mathrm{F}$.

\subsection{AC Inductor}

The selection of the AC inductance depends on the ripple current, $i_{\text {crpp }}$ and switching frequency $f_{s}$. The AC inductance is given as[ Singh et al, 2008],

$\mathrm{L}_{\mathrm{f}}=\sqrt{ } 3 \mathrm{mV}_{\mathrm{dc}} /\left\{12 * \mathrm{a} * \mathrm{f}_{\mathrm{s}} * \mathrm{i}_{\mathrm{crpp}}\right\}$

Considering, switching frequency $\left(\mathrm{f}_{\mathrm{s}}\right)$ of $10 \mathrm{kHz}$, modulation index $(\mathrm{m})$ equal to 1 , DC bus voltage $\left(\mathrm{V}_{\mathrm{dc}}\right)$ of $700 \mathrm{~V}$, over load factor(a) equal to1.2, and using Eq. (3), the value of $\mathrm{AC}$ inductance $\left(\mathrm{L}_{\mathrm{f}}\right)$ is found $2.15 \mathrm{mH}$ and selected value of $\mathrm{L}_{\mathrm{f}}$ is $2.25 \mathrm{mH}$.

\subsection{Ripple Filter}

A first order high pass filter shown in Figure 1 tuned at half of the switching frequency is used to filter the high frequency noise from the voltage at the point of common coupling. A capacitor with series resistance is selected as a ripple filter. The value of

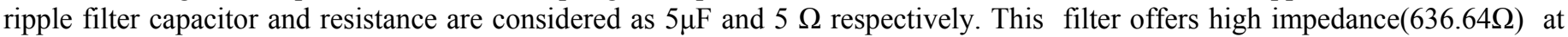
fundamental frequency and low impendence $(8.09 \Omega$ ) at half of the switching frequency (here $5 \mathrm{kHz}$ ) which prevents the flow of fundamental components at fundamental frequency in the ripple filter branch and allows the flow of high frequency noises through the ripple filter branch at higher than fundamental frequency.

\section{Control Algorithm of DSTATCOM}

Figure 2 shows the block diagram of control algorithm of a DSTATCOM based on the correlation and cross correlation function for extraction of reference source currents. Fundamental active and reactive power components of load currents for each phase are derived using correlation and cross correlation coefficients and the amplitude of fundamental active and reactive component of load currents are estimated using quadrature and in phase voltage unit templates, zero crossing detector (ZCD) and sample and hold circuit (SHC). The in phase and quadrature unit templates are estimated from phase value of PCC voltages. The zero crossing rising edge of quadrature and in phase voltage templates are the sensed position for extracting the per phase amplitude of fundamental active and reactive power components of load currents with sample and hold circuit. Similarly, amplitude of other phases active and reactive power components of the load currents are also extracted. For balancing the source currents, an average value is derived by the magnitude of active power current components of three phase load currents. The output of DC bus voltage proportional-integral (PI) regulator of VSC of DSTATCOM is added in the average amplitude of active power current component of the three phase load currents and this value (amplitude of active power components of load current) is multiplied with three phase in phase unit templates to compute the reference source active power components of currents. Similarly, reference source reactive power components of currents are estimated from the subtraction of an average value of fundamental reactive power components of load currents from the amplitude to output of voltage PI regulator and this value (amplitude of reactive current) which is multiplied with three phase quadrature components of unit templates. Total reference source currents are estimated by addition of reference active and reactive power components of source currents. Basic equation for estimation of different control signals of control algorithm are given below.

\subsection{Estimation of in- Phase and Quadrature Unit Voltage Templates}

The in phase unit templates are estimated using an amplitude of the PCC voltage $\left(\mathrm{V}_{\mathrm{s}}\right)$ and phase voltage $\left(\mathrm{v}_{\mathrm{sa}}, \mathrm{V}_{\mathrm{sb}}, \mathrm{V}_{\mathrm{sc}}\right)$ as 
$\mathrm{V}_{\mathrm{s}}=\sqrt{\frac{2\left(\mathrm{v}_{\mathrm{sa}}{ }^{2}+\mathrm{v}_{\mathrm{sb}}{ }^{2}+\mathrm{v}_{\mathrm{sc}}{ }^{2}\right)}{3}}$
$\mathrm{u}_{\text {sap }}=\frac{\mathrm{v}_{\mathrm{sa}}}{\mathrm{V}_{\mathrm{s}}}, \mathrm{u}_{\mathrm{sbp}}=\frac{\mathrm{v}_{\mathrm{sb}}}{\mathrm{V}_{\mathrm{s}}}, \mathrm{u}_{\mathrm{scp}}=\frac{\mathrm{v}_{\mathrm{sc}}}{\mathrm{V}_{\mathrm{s}}}$

and the quadrature unit template are computed as[Singh and Kumar, 2010],

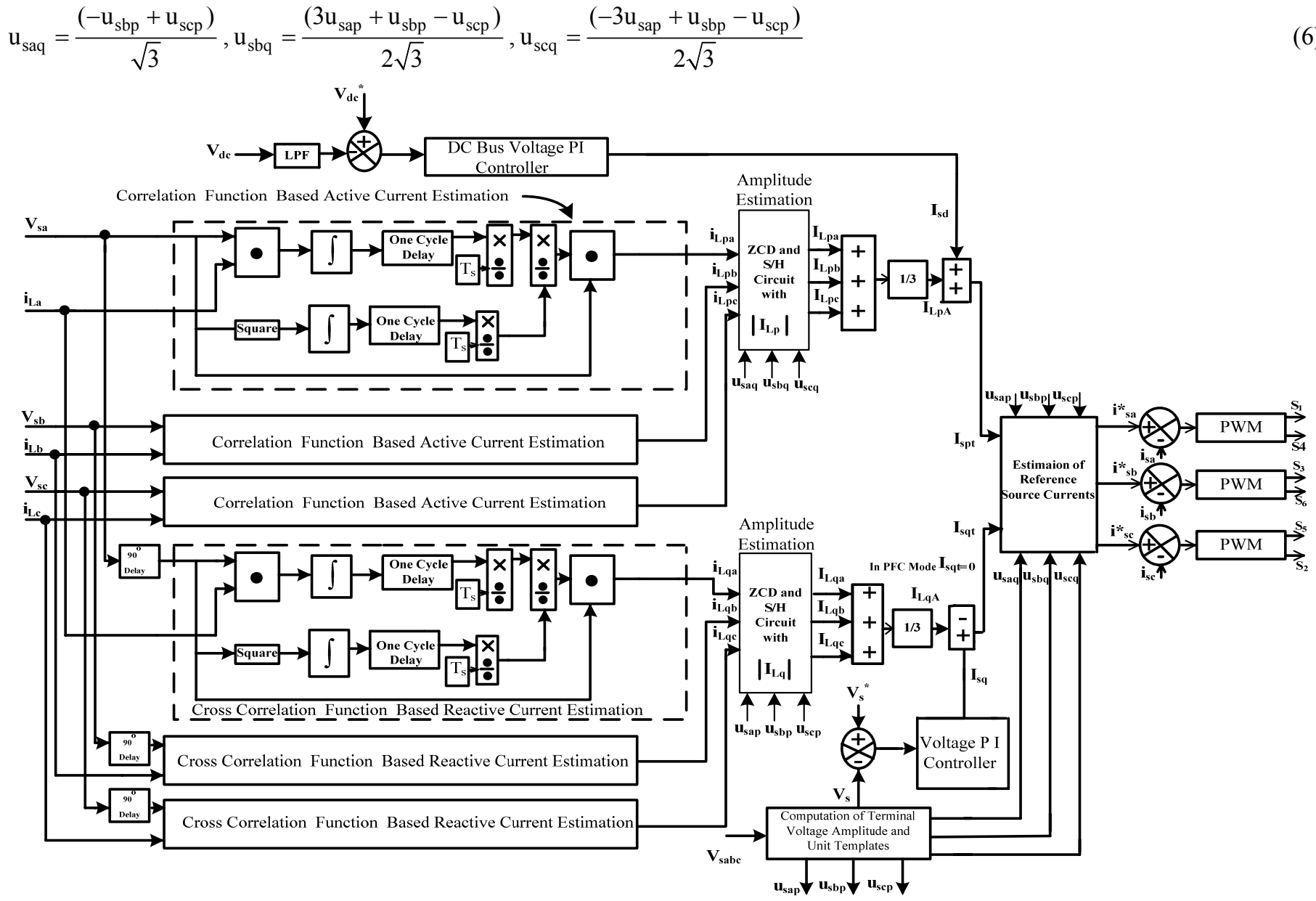

Figure 2. Generation of reference currents using correlation and cross correlation function based control algorithm

\subsection{Estimation of Fundamental Active and Reactive Power Components of Load Currents}

Fundamental active and reactive power components of load currents are estimated by using the correlation and cross-correlation function coefficients respectively. Considering that balanced phase ' $A$ ' supply voltage $v_{s a}(t)$ and distorted load current $i_{L a}(t)$ and their time varying (instantaneous) expressions are as,

$\mathrm{v}_{\mathrm{sa}}(\mathrm{t})=\mathrm{V}_{\mathrm{ma}} \sin \omega \mathrm{t}$

$\mathrm{i}_{\mathrm{La}}(\mathrm{t})=\mathrm{I}_{\mathrm{La} 1} \sin \left(\omega \mathrm{t}-\phi_{1}\right)+\mathrm{I}_{\mathrm{La} 3} \sin \left(3 \omega \mathrm{t}-\phi_{3}\right)+\mathrm{I}_{\mathrm{La} 5} \sin \left(5 \omega \mathrm{t}-\phi_{5}\right) \ldots$

The norms of $\mathrm{v}_{\mathrm{sa}}(\mathrm{t})$ and $\mathrm{i}_{\mathrm{La}}(\mathrm{t})$ are given as

$\left\|\mathrm{v}_{\mathrm{sa}}(\mathrm{t})\right\|^{2}=\frac{1}{\mathrm{~T}_{\mathrm{s}}} \int_{\mathrm{t}-\mathrm{Ts}}^{\mathrm{t}} \mathrm{v}_{\mathrm{sa}}{ }^{2}(\mathrm{t}) \mathrm{dt}$

$\left\|i_{L a}(t)\right\|^{2}=\frac{1}{T_{s}} \int_{t-T s}^{t} i_{L a}(t)^{2} d t$ 
where $T_{s}$ is equal to time period of one cycle. The product of $v_{s a}(t), i_{L a}(t)$ can be expressed as,

$$
\left[\mathrm{v}_{\mathrm{sa}}(\mathrm{t}), \mathrm{i}_{\mathrm{La}}(\mathrm{t})\right]=\frac{1}{\mathrm{~T}_{\mathrm{s}}} \int_{t-T s}^{\mathrm{t}} \mathrm{v}_{\mathrm{sa}}(\mathrm{t}) \cdot \mathrm{i}_{\mathrm{La}}(\mathrm{t}) \mathrm{dt}
$$

From equations (6), (7) and (8) the correlation coefficient is defined as,

$$
\mathrm{r}=\left[\mathrm{v}_{\mathrm{sa}}(\mathrm{t}), \mathrm{i}_{\mathrm{La}}(\mathrm{t})\right] /\left[\left\|\mathrm{v}_{\mathrm{sa}}(\mathrm{t})\right\| \cdot\left\|\mathrm{i}_{\mathrm{La}}(\mathrm{t})\right\|\right]
$$

From equations (6), (7), (8) and (9) the fundamental active power component of load current of phase 'A' ( $\mathrm{i}_{\mathrm{Lpa}}$ ) is defined as,

$$
\mathrm{i}_{\mathrm{Lpa}}(\mathrm{t})=\frac{\left[\mathrm{v}_{\mathrm{sa}}(\mathrm{t}), \mathrm{i}_{\mathrm{La}}(\mathrm{t})\right]}{\left\|\mathrm{v}_{\mathrm{sa}}(\mathrm{t})\right\|^{2}} \cdot \mathrm{v}_{\mathrm{sa}}(\mathrm{t})
$$

Similarly, other phase fundamental active power component of load currents $\left(\mathrm{i}_{\mathrm{Lpb}}\right.$ and $\left.\mathrm{i}_{\mathrm{Lpc}}\right)$ are also extracted.

The cross correlation is used to estimate the fundamental reactive power component of load current. It is derived after $90^{\circ}$ delay of PCC phase voltage $\left(\mathrm{v}_{\mathrm{sqa}}, \mathrm{v}_{\mathrm{sqb}}, \mathrm{V}_{\mathrm{sqc}}\right)$. Phase 'A' fundamental reactive power component of load current can be defined as,

$\mathrm{i}_{\mathrm{Lqa}}(\mathrm{t})=\frac{\left[\mathrm{v}_{\mathrm{sqa}}(\mathrm{t}), \mathrm{i}_{\mathrm{La}}(\mathrm{t})\right]}{\left\|\mathrm{v}_{\mathrm{sqa}}(\mathrm{t})\right\|^{2}} \cdot \mathrm{v}_{\mathrm{sqa}}(\mathrm{t})$

where $\mathrm{v}_{\text {sqa }}(\mathrm{t})=\frac{\left(-\mathrm{v}_{\mathrm{sbp}}+\mathrm{v}_{\mathrm{scp}}\right)}{\sqrt{3}}$

Similarly, other phase fundamental reactive power component of load currents ( $\mathrm{i}_{\mathrm{Lqb}}$ and $\mathrm{i}_{\mathrm{Lqc}}$ ) are also estimated.

\subsection{Estimation of Amplitude of Active Power and Reactive Power of Current Components of Load Currents}

The amplitude of active and reactive power component of load currents are estimated using quadrature and in phase voltage unit templates, zero crossing detector (ZCD) and sample and hold circuit(SHC). The in phase $\left(\mathrm{u}_{\mathrm{spa}}, \mathrm{u}_{\mathrm{spb}}, \mathrm{u}_{\mathrm{spc}}\right)$ and quadrature $\left(\mathrm{u}_{\mathrm{sqa}}, \mathrm{u}_{\mathrm{sqb}}\right.$, $\mathrm{u}_{\mathrm{sqc}}$ ) unit templates are estimated from phase value of PCC voltages. To extract the amplitude of the fundamental active power component of load current in phase of phase voltage, a zero crossing detector is used with quadrature unit template in respective phase. A sample and hold circuit is used with load fundamental active power component as the input signal and zero crossing detector output $\left(\mathrm{O}_{\mathrm{ZCD} 1}\right)$ as rising edge trigger pulse. The magnitude of the output of sample and hold circuit $\left(\mathrm{O}_{\mathrm{SHCl}}\right)$ is considered as the amplitude of phase A fundamental active power component of load current $\left(\mathrm{I}_{\mathrm{Lpa}}\right.$ ). Similarly, other phase B and phase C active power current components of load currents $\left(\mathrm{I}_{\mathrm{Lpb}}\right.$ and $\left.\mathrm{I}_{\mathrm{Lpc}}\right)$ are also estimated. To extract the magnitude of fundamental reactive power component of the load current, another zero crossing detector is used with in phase voltage unit template and sample and hold circuit. Sample and hold circuit is used with fundamental reactive power component of load current as a input and output of zero crossing detector $\left(\mathrm{O}_{\mathrm{ZCD} 2}\right)$ as a trigger pulse. The magnitude of the output of sample and hold circuit $\left(\mathrm{O}_{\mathrm{SHC2}}\right)$ is considered as the amplitude of phase ' $\mathrm{A}$ ' reactive power component of load current $\left(\mathrm{I}_{\mathrm{Lqa}}\right)$. Similarly, other phase ' $\mathrm{B}$ ' and phase ' $\mathrm{C}$ ' reactive power current components $\left(\mathrm{I}_{\mathrm{Lqb}}, \mathrm{I}_{\mathrm{Lqc}}\right)$ are also estimated.

\subsection{Estimation of Average Amplitude of Active and Reactive Power Current Components of Load Currents}

The average fundamental amplitude of active and reactive power components of the three phase load currents are estimated using amplitude of load active and reactive power currents. Average value is given for extraction of three phase reference source current as,

$$
\begin{aligned}
& I_{L p A}=\frac{I_{L p a}+I_{L p b}+I_{L p c}}{3} \\
& I_{L q A}=\frac{I_{L q a}+I_{L q b}+I_{L q c}}{3}
\end{aligned}
$$

3.5. Amplitude of Active Power Component of Reference Source Currents 
To compute amplitude of active power components of source current, a reference DC bus voltage is compared with sensed DC voltage. The difference between this error in DC bus voltage of the DSTATCOM at the $\mathrm{n}^{\text {th }}$ sampling instant is

$\mathrm{V}_{\text {dcer }}(\mathrm{n})=\mathrm{V}_{\text {dcref }}(\mathrm{n})-\mathrm{V}_{\text {dc }}(\mathrm{n})$

where, $V_{\text {dcref }}(n)$ is the reference DC bus voltage and $V_{d c(n)}$ is the sensed DC bus voltage of DSTATCOM.

The output of DC bus PI controller for maintaining DC bus voltage of the DSTATCOM of the $\mathrm{n}^{\text {th }}$ sampling instant is expressed as,

$$
\mathrm{I}_{\mathrm{sd}}(\mathrm{n})=\mathrm{I}_{\mathrm{sd}}(\mathrm{n}-1)+\mathrm{K}_{\mathrm{pd}}\left\{\mathrm{V}_{\mathrm{dcer}(\mathrm{n})}-\mathrm{V}_{\text {dcer(n-1) }}\right\}+\mathrm{K}_{\mathrm{id}} \mathrm{V}_{\text {dce }}
$$

where $I_{\mathrm{sd}}(\mathrm{n})$ considered as the active power component of source current requirement for the self supporting DC bus of the DSTATCOM and $\mathrm{K}_{\mathrm{pd}}$ and $\mathrm{K}_{\mathrm{id}}$ are the proportional and integral gain constants of the DC bus PI voltage controller.

The amplitude of active power component of the reference source current is computed as the addition of active power requirement for the self supporting DC bus of the DSTATCOM reference currents and average magnitude of active power component of the load currents as,

$\mathrm{I}_{\mathrm{spt}}=\mathrm{I}_{\mathrm{sd}}+\mathrm{I}_{\mathrm{LpA}}$

\subsection{Amplitude of Reactive Power Component of Reference Source Currents}

The amplitude of reactive power component of the reference source current is calculating using a voltage PI controller over the amplitude of the PCC voltage $\left(V_{s}\right)$ and its reference value $\left(V_{s}^{*}\right)$. The output of the voltage PI controller for regulated load terminal voltage at the $\mathrm{n}^{\text {th }}$ sampling instant is expressed as,

$$
\mathrm{I}_{\mathrm{sq}}(\mathrm{n})=\mathrm{I}_{\mathrm{sq}}(\mathrm{n}-1)+\mathrm{K}_{\mathrm{pq}}\left\{\mathrm{V}_{\mathrm{e}(\mathrm{n})^{-}}-\mathrm{V}_{\mathrm{e}}(\mathrm{n}-1)\right\}+\mathrm{K}_{\mathrm{iq}} \mathrm{V}_{\mathrm{e}}(\mathrm{n})
$$

where $\mathrm{V}_{\mathrm{e}}$ is equal to $\left(\mathrm{V}_{\mathrm{s}}{ }^{*}-\mathrm{V}_{\mathrm{s}}\right)$ and it is the error in amplitude of the PCC voltage and reference terminal voltage. $\mathrm{K}_{\mathrm{pq}}$ and $\mathrm{K}_{\mathrm{iq}}$ are the proportional and integral gains of the PI controller over the PCC voltage.

The amplitude of reactive power component of the reference source current is computed as the difference of output of the voltage PI controller and average reactive power component of load currents as,

$$
\mathrm{I}_{\mathrm{sq}}=\mathrm{I}_{\mathrm{sq}}-\mathrm{I}_{\mathrm{dqA}}
$$

\subsection{Estimation of Source Reference Currents and Generation of Gating Pulses}

Three phase source reference currents are computed using amplitude of active and reactive power component of source current and in phase and quadrature unit voltage templates. Three phase source reference active and reactive power current components are estimated as

$$
\begin{array}{ll}
i_{\text {sap }}=I_{\text {spt }} * u_{\text {sap }}, i_{\text {sbp }}=I_{\text {spt }} * u_{\text {sbp }}, & i_{\text {scp }}=I_{\text {spt }} * u_{\text {scp }} \\
i_{\text {saq }}=I_{\text {sqt }} * u_{\text {saq }}, i_{\text {sbq }}=I_{\text {sqt }} * u_{\text {sbq }}, & i_{\text {scq }}=I_{\text {sqt }} * u_{\text {scq }}
\end{array}
$$

Total reference source currents are calculated after addition of reference active and reactive power current components as

$i_{\text {sa }}^{*}=i_{\text {sap }}+i_{\text {saq, }}, i_{\text {sb }}^{*}=i_{\text {sbp }}+i_{\text {sbq }}, i_{\text {sc }}^{*}=i_{\text {scp }}+i_{\text {scq }}$

For gating signal generation, extracted three phase reference source currents $\left(\mathrm{i}_{\mathrm{sa}}, \mathrm{i}_{\mathrm{sb}}, \mathrm{i}_{\mathrm{sc}}\right)$ are compared with source currents $\left(i_{\mathrm{sa}}, \mathrm{i}_{\mathrm{sb}}, \mathrm{i}_{\mathrm{sc}}\right)$. These current errors are amplified using a proportional controller and outputs of current controller are compared with carrier wave signal to generate PWM pulses for the VSC switches $\mathrm{S}_{1}, \mathrm{~S}_{4}, \mathrm{~S}_{3}, \mathrm{~S}_{6}, \mathrm{~S}_{5}, \mathrm{~S}_{2}$ of DSTATCOM.

\section{Development of MATLAB Based Model}

A model of the three leg VSC based DSTATCOM connected to a three-phase system is developed and its performance is simulated in MATLAB environment using SIMULINK and Sim Power System(SPS) toolboxes. The developed MATLAB model is shown in Figure 3. The ripple filter is connected to a DSTATCOM for filtering the ripple in the voltage at the PCC. The system data are given in the Appendix. The control algorithm for the DSTATCOM is also modeled in MATLAB. The reference source currents are derived from the sensed PCC voltages $\left(\mathrm{v}_{\mathrm{sa}}, \mathrm{v}_{\mathrm{sb}}, \mathrm{v}_{\mathrm{sc}}\right)$, load currents $\left(\mathrm{i}_{\mathrm{La}}, \mathrm{i}_{\mathrm{Lb}}, \mathrm{i}_{\mathrm{Lc}}\right)$ and the DC bus voltage of DSTATCOM $\left(\mathrm{v}_{\mathrm{dc}}\right)$. A pulse width modulated (PWM) current controller is used over the reference and sensed source currents to generate the gating signals for the IGBTs of the VSC of the DSTATCOM. 


\section{Results and Discussion}

The performance of the correlation and cross-correlation based control algorithm for the three-phase DSTATCOM is simulated for PFC (Power Factor Correction) and ZVR (Zero Voltage Regulation) modes of operation with unbalance in the loads currents. The performance of DSTATCOM is analyzed under time varying loads and the results are discussed below.

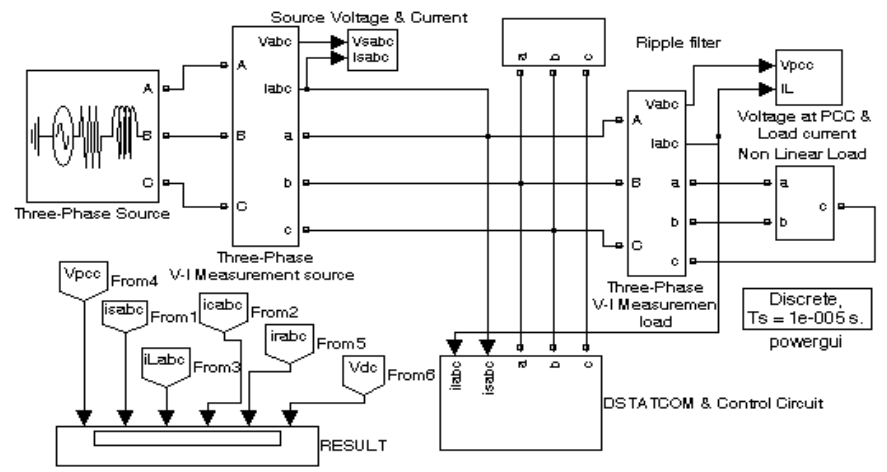

Figure 3. MATLAB based simulation model of DSTATCOM

\subsection{Performance of Control Algorithm}

Figure 4 shows the various intermediate signals of the control algorithm which include fundamental active power components of load current $\left(\mathrm{i}_{\mathrm{Lp}}\right)$, reactive power components of load current $\left(\mathrm{i}_{\mathrm{Lq}}\right)$, average amplitude value of active power component of load currents $\left(\mathrm{I}_{\mathrm{LpA}}\right)$ and reactive currents $\left(\mathrm{I}_{\mathrm{LqA}}\right)$, output of DC bus PI controller $\left(\mathrm{I}_{\mathrm{sd}}\right)$ and voltage PI controller $\left(\mathrm{I}_{\mathrm{sq}}\right)$, amplitude of active $\left(I_{\text {spt }}\right)$ and reactive $\left(I_{\mathrm{sqt}}\right)$ power component of reference source current, three phase source reference active power $\left(\mathrm{i}_{\mathrm{sp}}\right)$ and reactive power $\left(\mathrm{i}_{\mathrm{sq}}\right)$ components of current and three phase reference current $\left(\mathrm{i}_{\mathrm{s}}{ }^{*}\right)$ respectively. These signals are shown with respect to AC supply mains voltage $\left(\mathrm{v}_{\mathrm{s}}\right)$ and load currents $\left(\mathrm{i}_{\mathrm{L}}\right)$. It clearly demonstrates the accurate extraction of control signals even under distorted load currents.

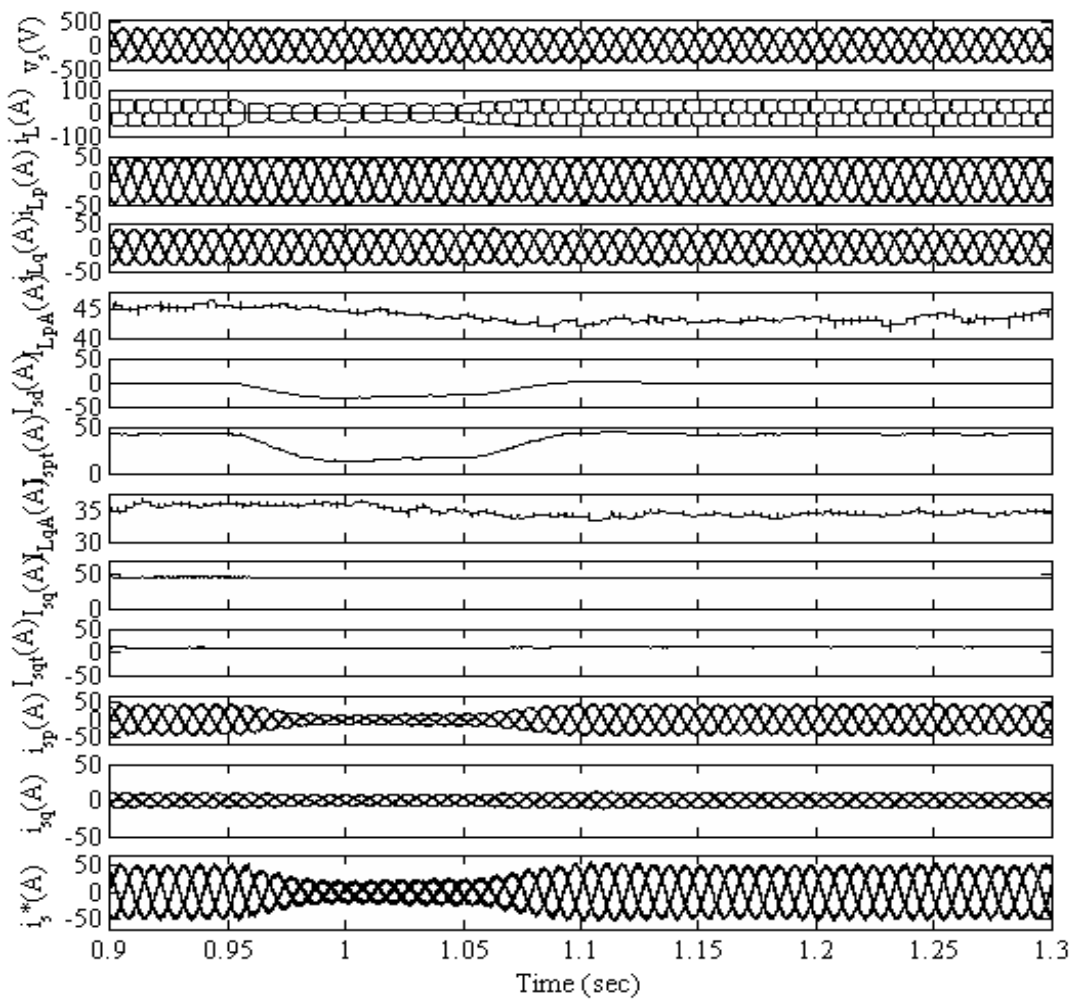

Figure 4. Various intermediate signals of control algorithm with respect to AC supply mains $\left(\mathrm{v}_{\mathrm{s}}\right)$ and load currents $\left(\mathrm{i}_{\mathrm{L}}\right)$ 


\subsection{Performance of DSTATCOM in PFC Mode}

The dynamic performance of a three-leg VSC based DSTATCOM for PFC mode of operation under a linear load is shown in Figure 5. Performance indices are as phase voltage at $\mathrm{PCC}\left(\mathrm{v}_{\mathrm{s}}\right)$, source currents $\left(\mathrm{i}_{\mathrm{s}}\right)$, load currents $\left(\mathrm{i}_{\mathrm{L}}\right)$, compensator currents $\left(\mathrm{i}_{\mathrm{Ca}}\right.$, $\left.\mathrm{i}_{\mathrm{Cb}}, \mathrm{i}_{\mathrm{Cc}}\right)$, and $\mathrm{DC}$ bus voltage $\left(\mathrm{V}_{\mathrm{dc}}\right)$ which are shown under varying loads (at $\mathrm{t}=0.95 \mathrm{~s}$ to $\left.1.05 \mathrm{~s}\right)$ conditions. It clearly shows the satisfactory operation of DSTATCOM.

Similarly, current and voltage source type of harmonics generating nonlinear loads are also connected to the supply system. The dynamic performance of DSTATCOM and waveforms of phase ' $\mathrm{A}$ ' voltage at PCC $\left(\mathrm{v}_{\mathrm{sa}}\right)$, source current $\left(\mathrm{i}_{\mathrm{sa}}\right)$ and load current $\left(\mathrm{i}_{\mathrm{La}}\right)$ are shown in Figure 6 and Figures 7(a-c) respectively in case of current source type of harmonic generating load. In Figure 7(a-c), THD $\%$ of the phase ' $\mathrm{A}$ ' at PCC voltage, source current, load current are $2.02 \%, 3.55 \%$ and $24.31 \%$ respectively. Dynamic performance of voltage source type of harmonics generating nonlinear load and waveform of phase 'A' voltage at PCC ( $\left.\mathrm{v}_{\mathrm{sa}}\right)$, source current $\left(\mathrm{i}_{\mathrm{sa}}\right)$ and load current $\left(\mathrm{i}_{\mathrm{La}}\right)$ are shown in Figure 8 and Figures 9 (a-c) respectively. In Figure 9(a-c), THD\% of the phase 'A' at PCC voltage, source current, load current are $3.43 \%, 3.45 \%$ and $44.87 \%$ respectively. It is observed that the DSTATCOM is able to perform the functions of load balancing, harmonic elimination and power factor correction from above discussion.

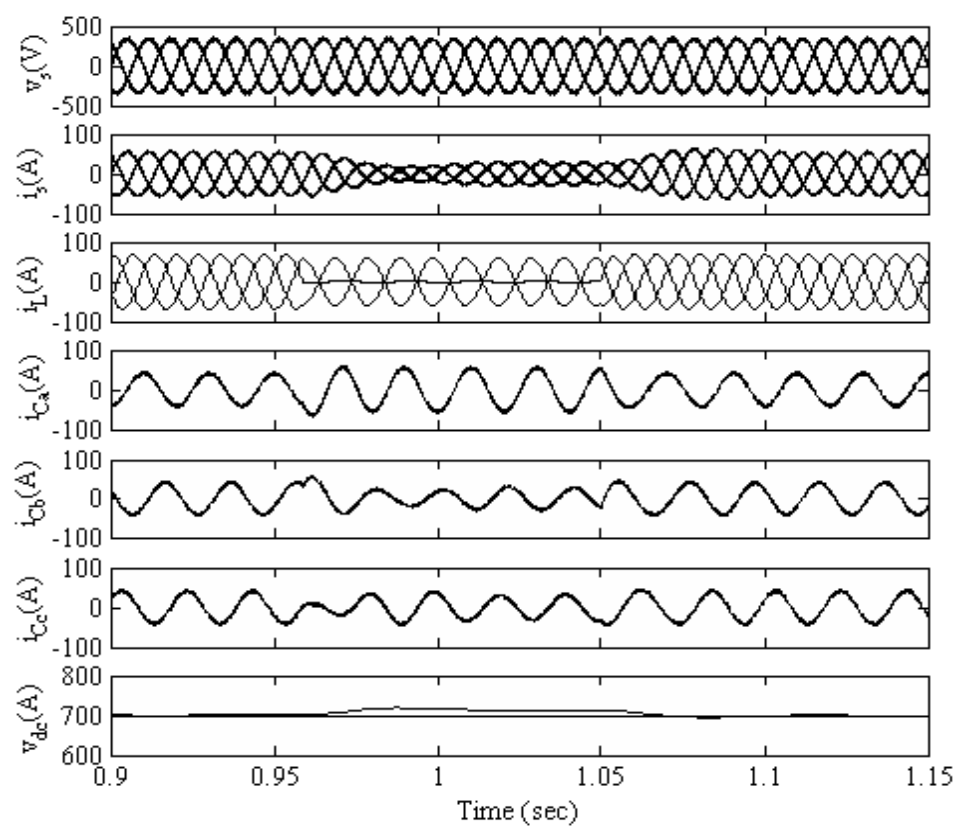

Figure 5. Dynamic performance of DSTATCOM under varying linear load in PFC mode

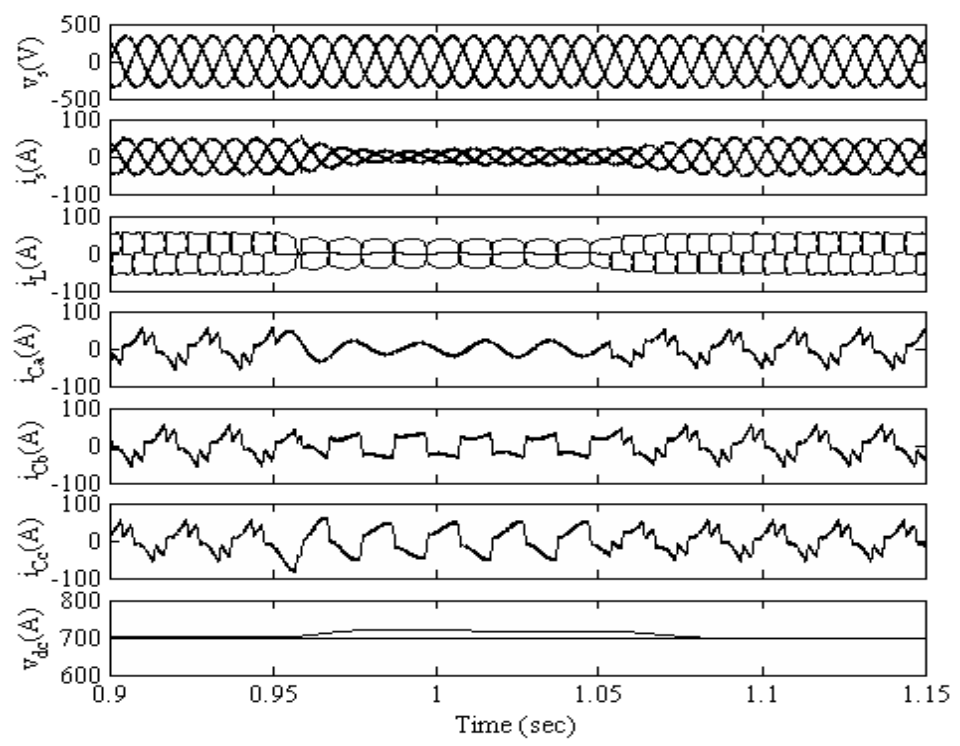

Figure 6. Dynamics performance of DSTATCOM under varying nonlinear load (current source type) in PFC mode 

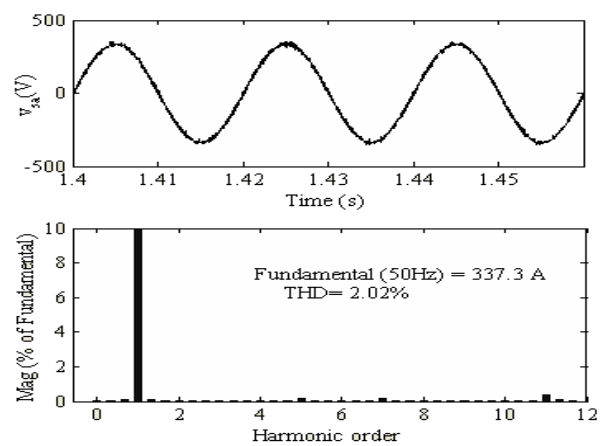

(a)
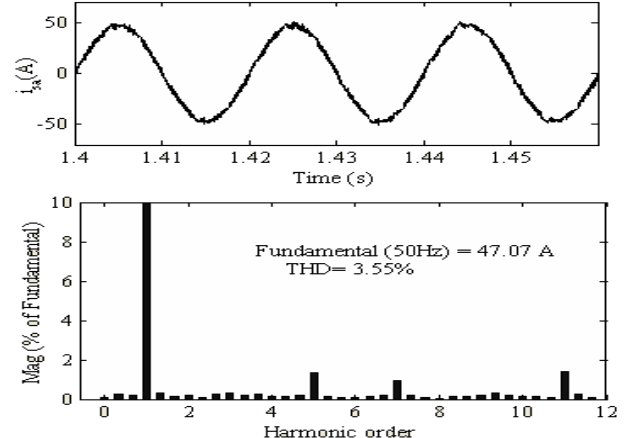

(b)
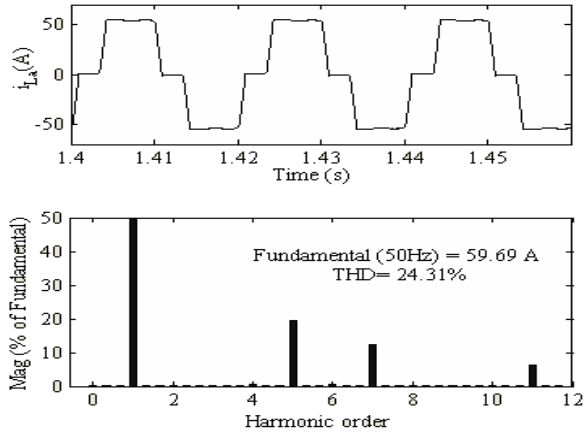

(c)

Figure 7. Waveforms, THD and harmonic spectra of (a) PCC voltage of phase 'A' (b) source current of phase 'A' (c) load current of phase ' $\mathrm{A}$ ' in PFC mode
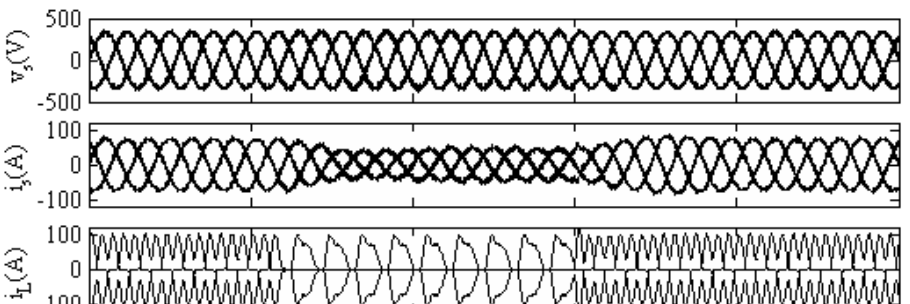

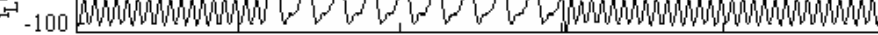

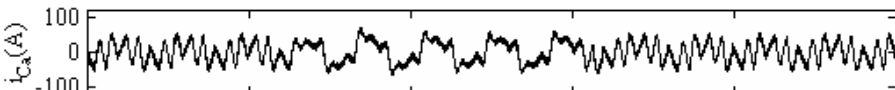

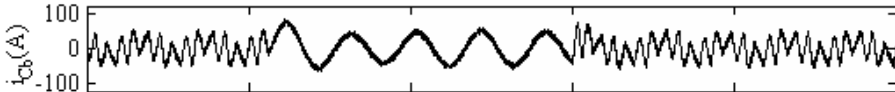
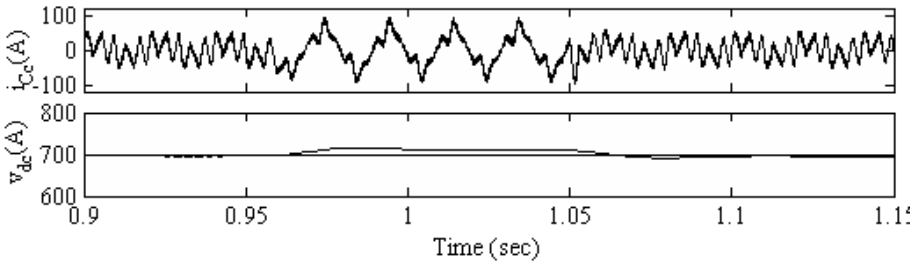

Figure 8 . Dynamics performance of DSTATCOM under varying nonlinear load (voltage source type) in PFC mode
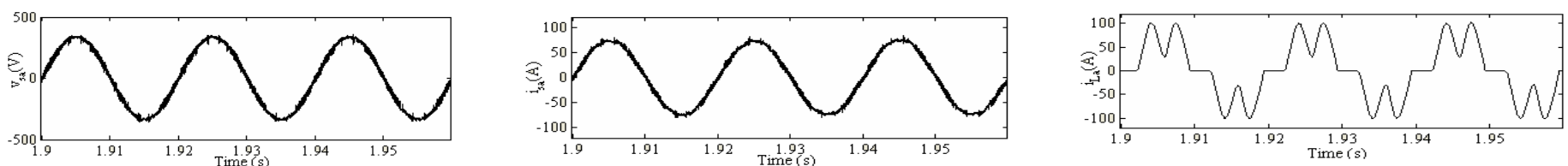

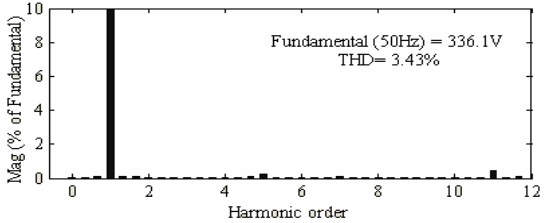

(a)

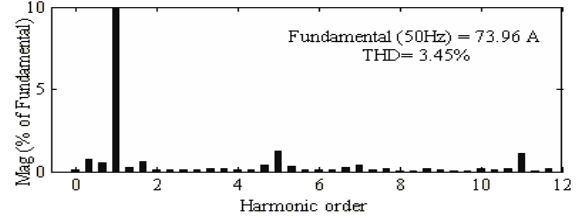

(b)

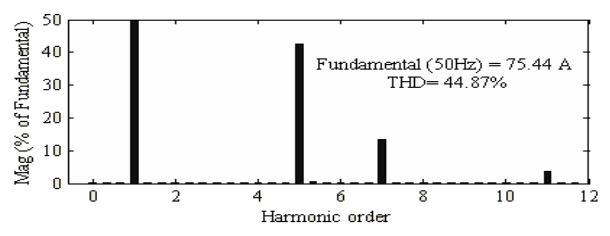

(c)

Figure 9. Waveforms, THD and harmonic spectra of (a) PCC voltage of phase 'A' (b) source current of phase 'A' (c) load current of phase ' $\mathrm{A}$ ' in PFC mode

\subsection{Performance of DSTATCOM at ZVR Mode}

In ZVR mode, the amplitude of PCC voltage is regulated to the reference amplitude by injecting the required reactive power compensation. Figure 10 shows the dynamic performance of the DSTATCOM used in three phase system for reactive power 
compensation with voltage regulation and load balancing of linear loads (at $\mathrm{t}=0.95 \mathrm{~s}$ to $1.05 \mathrm{~s}$ ). The performance indices are as PCC phase voltages $\left(\mathrm{v}_{\mathrm{s}}\right)$, balanced source currents $\left(\mathrm{i}_{\mathrm{s}}\right)$, load currents $\left(\mathrm{i}_{\mathrm{L}}\right)$, compensator currents $\left(\mathrm{i}_{\mathrm{Ca}}, \mathrm{i}_{\mathrm{Cb}}, \mathrm{i}_{\mathrm{Cc}}\right)$, amplitude of voltages at PCC $\left(\mathrm{V}_{\mathrm{s}}\right)$ and $\mathrm{DC}$ bus voltage $\left(\mathrm{v}_{\mathrm{dc}}\right)$ under time varying linear loads.

Similarly, performance of DSTATCOM is found satisfactory under current and voltage source types of harmonics generating nonlinear loads. The dynamic performance of DSTATCOM and waveforms of phase 'A' voltage at PCC $\left(\mathrm{v}_{\mathrm{sa}}\right)$, source current $\left(\mathrm{i}_{\mathrm{sa}}\right)$ and load current $\left(\mathrm{i}_{\mathrm{La}}\right)$ are shown in Figure 11 and Figures 12(a-c) respectively in case of three phase controlled rectifier with series ' $R$ ' and ' $L$ ' load used as current source type of harmonic generating nonlinear load. In Figure 12(a-c), THD \% of the phase 'A' at PCC voltage, source current, load current are $2.06 \%, 3.76 \%$ and $24.53 \%$ respectively. Three phase un-controlled rectifier with parallel ' $\mathrm{R}$ ' and ' $\mathrm{C}$ ' is modeled as a voltage source type of harmonics generating nonlinear load. Dynamic performance of a DSTACOM under a voltage source type of harmonics generating nonlinear load and waveform of phase 'A' voltage at PCC $\left(\mathrm{v}_{\mathrm{sa}}\right)$, source current $\left(\mathrm{i}_{\mathrm{sa}}\right)$ and load current $\left(\mathrm{i}_{\mathrm{La}}\right)$ are shown in Figure 13 and Figures 14 (a-c) respectively. In Figure 14(a-c), THD \% of the phase 'A' at PCC voltage, source current, load current are 3.59\%, 3.39\% and $44.45 \%$ respectively. It may be observed that the THD of the source current and PCC voltage are within IEEE-519-1992 standard limit of 5\%. Table 1 shows the summarized results demonstrating the performance of DSTATCOM. These results show satisfactory performance of DSTATCOM for harmonic elimination, reactive power compensation and load balancing for variety of loads.

Table 1. Performance of DSTATCOM in different operating modes

\begin{tabular}{|c|c|c|c|c|}
\hline \multirow{2}{*}{ Operating mode } & \multirow{2}{*}{ Performance parameters } & \multirow{2}{*}{$\begin{array}{l}\text { Linear load } \\
\text { (Lagging power } \\
\text { factor load) }\end{array}$} & \multicolumn{2}{|c|}{ Nonlinear load } \\
\hline & & & $\begin{array}{l}\text { Current source type } \\
\text { (3-phase controlled } \\
\left.\text { rectifier, } \alpha=30^{\circ}\right)\end{array}$ & $\begin{array}{l}\text { Voltage source type } \\
\text { (3-phase un-controlled rectifier } \\
\text { with ' } R \text { ' and ' } C \text { ' load ) }\end{array}$ \\
\hline \multirow{3}{*}{ PFC mode } & PCC voltage $(\mathrm{V}), \% \mathrm{THD}$ & $238.1(1.61 \%)$ & $238.86(2.02 \%)$ & $237.65(3.43 \%)$ \\
\hline & Supply current (A), \%THD & $38.76(2.67 \%)$ & $33.28(3.55 \%)$ & $52.29(3.55 \%)$ \\
\hline & Load current (A), \%THD & $48.38(0.1 \%)$ & $42.20(24.31 \%)$ & $53.34(44.87 \%)$ \\
\hline \multirow{4}{*}{ ZVR mode } & PCC voltage (V), \% THD & $239.7(1.67 \%)$ & $239.63(2.06 \%)$ & $239.49(3.59 \%)$ \\
\hline & Source current (A),\%THD & $40.32(2.05 \%)$ & $34.31(3.76 \%)$ & $53.85(3.76 \%)$ \\
\hline & Load current (A), \%THD & $48.69(0.08 \%)$ & $42.23(24.53 \%)$ & $53.73(44.45 \%)$ \\
\hline & DC bus voltage $(\mathrm{V})$ & 700 & 700 & 700 \\
\hline
\end{tabular}

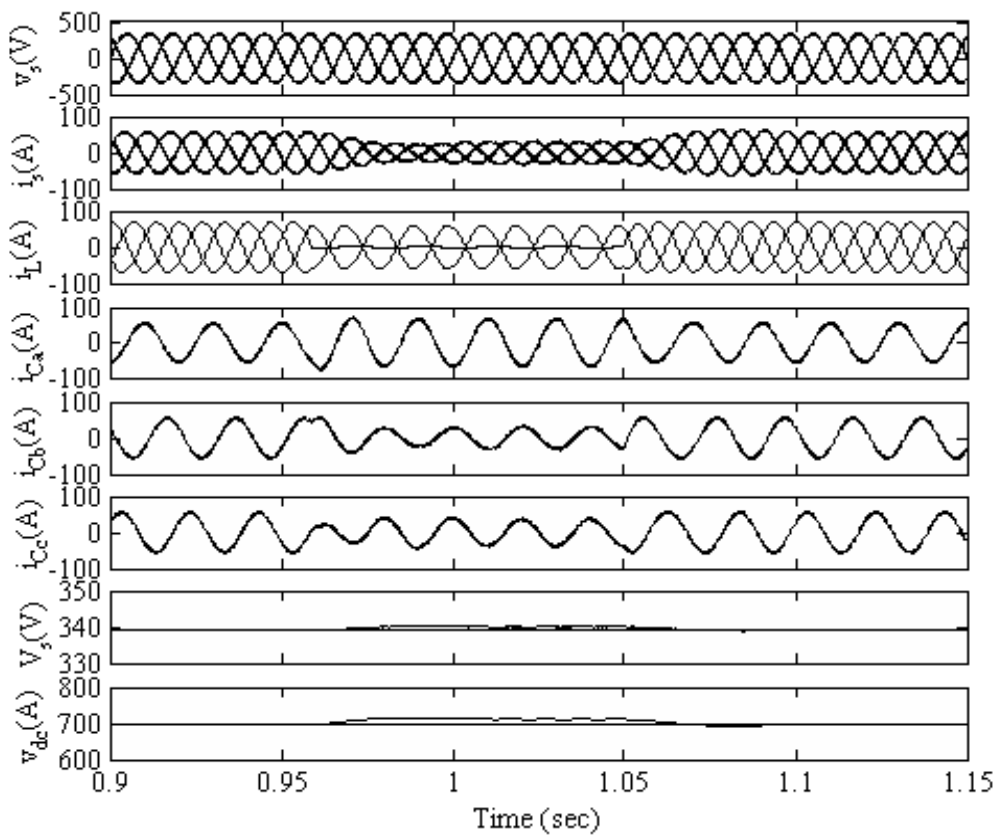

Figure 10. Dynamics performance of DSTATCOM under varying linear load in ZVR mode 


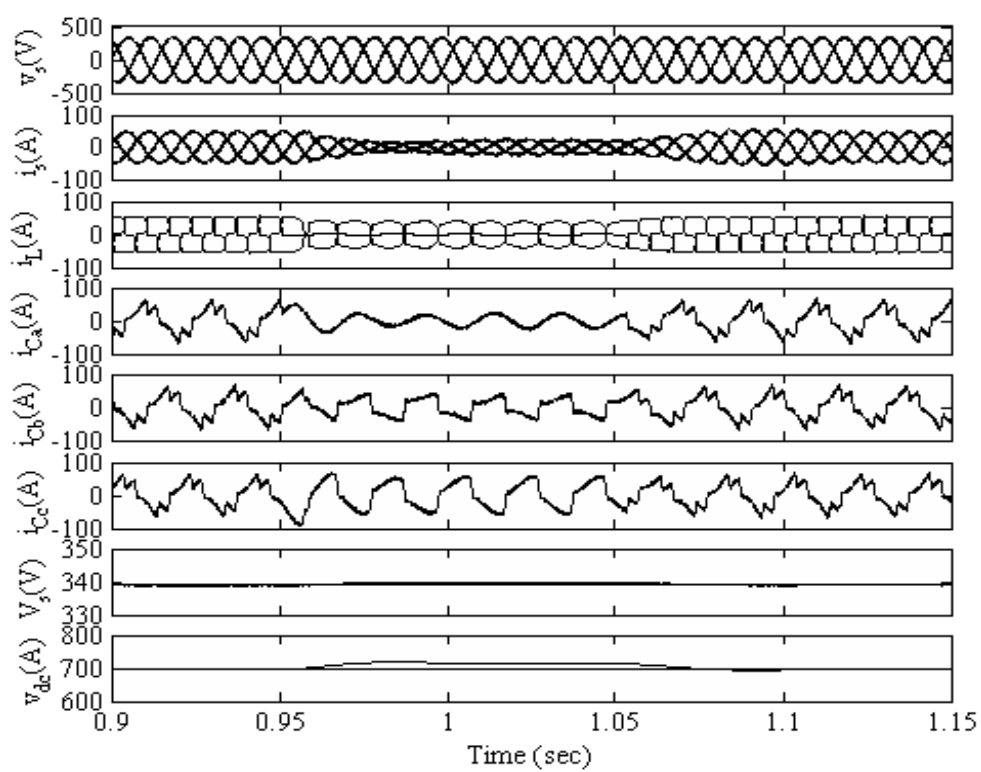

Figure 11. Dynamic performance of DSTATCOM under varying nonlinear load (current source type) in ZVR mode
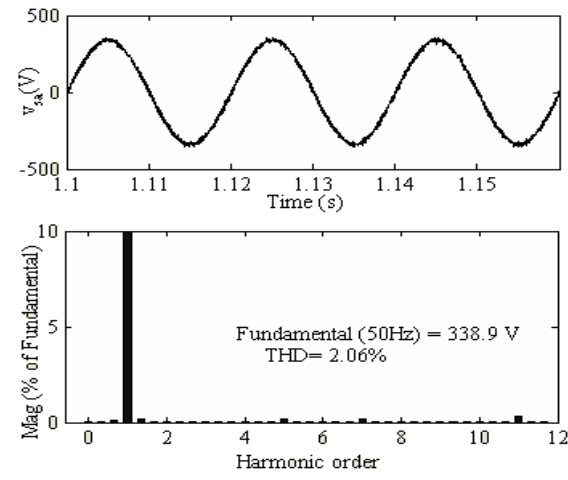

(a)
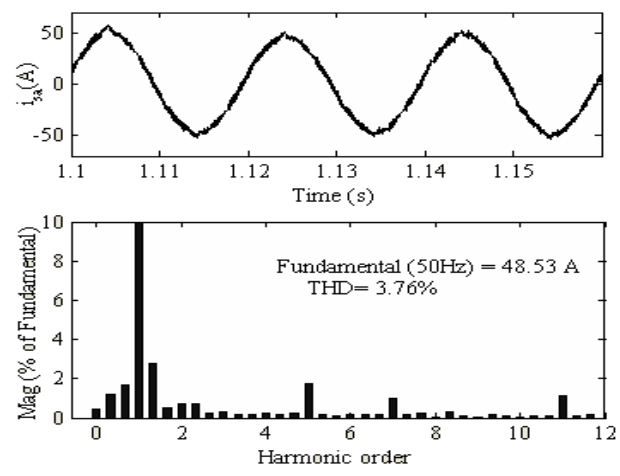

(b)
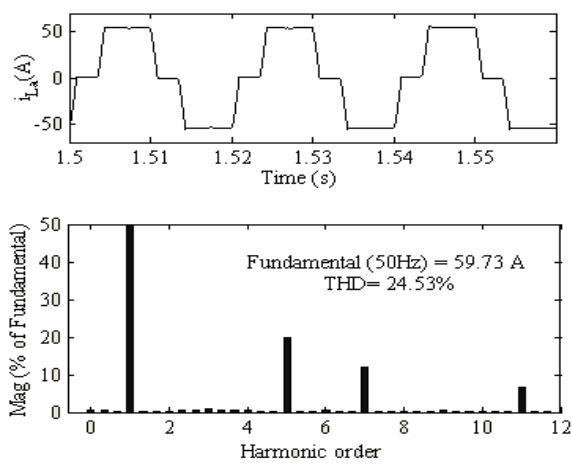

(c)

Figure 12. Waveforms, THD and harmonic spectra of (a) PCC voltage of phase 'A' (b) source current of phase 'A' (c) load current of phase ' $A$ ' in ZVR mode

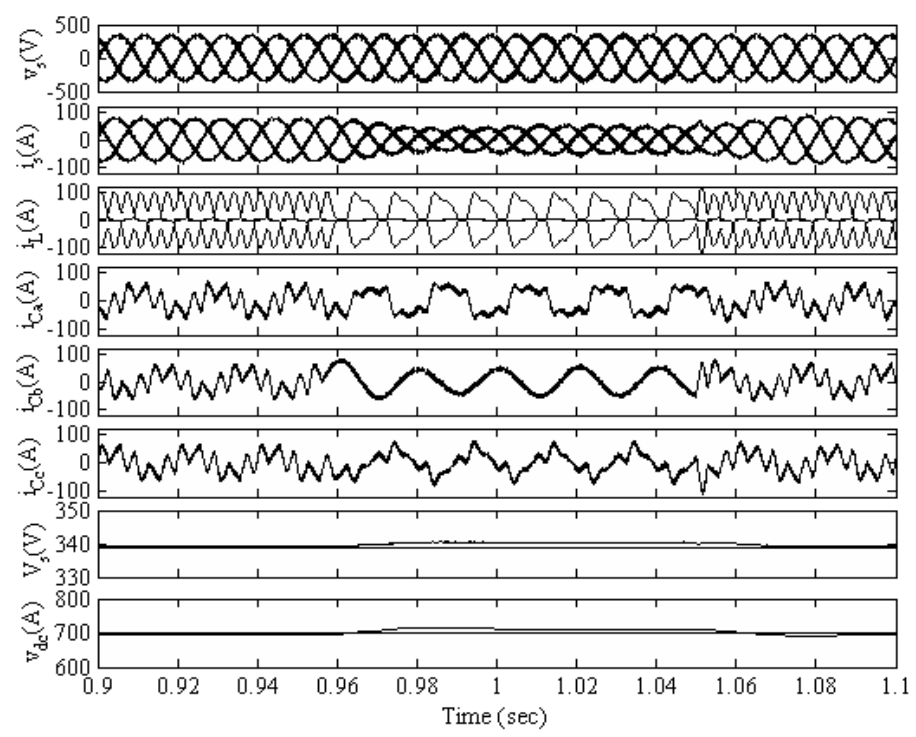

Figure 13. Dynamic performance of DSTATCOM under varying nonlinear load (voltage source type) in ZVR mode 

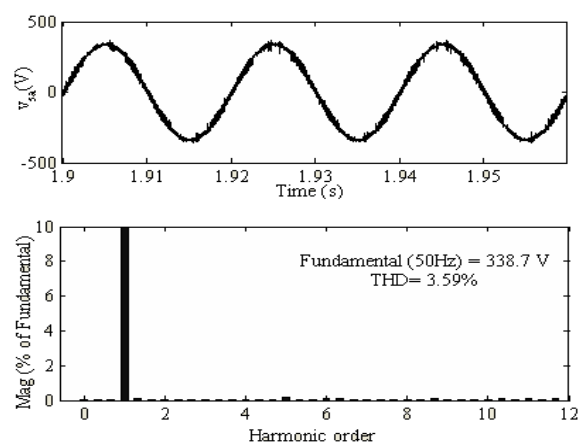

(a)
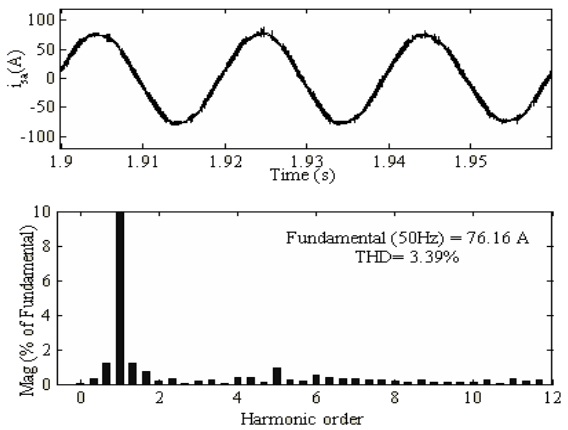

(b)
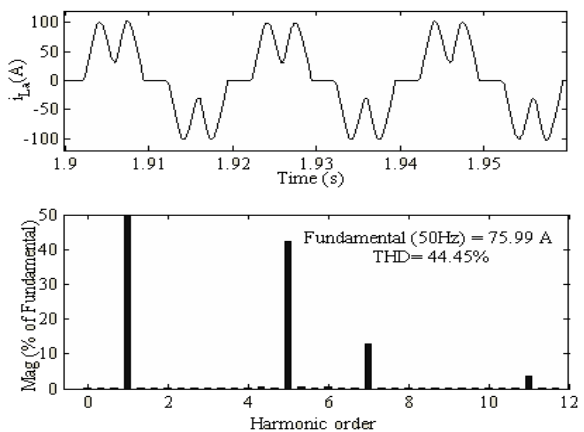

(c)

Figure 14. Waveforms, THD and harmonic spectra of (a) PCC voltage of phase A (b) source current of phase A (c) load current of

\section{Conclusions} phase $\mathrm{A}$ in ZVR mode

The design and control of a DSTATCOM have been carried out for a three phase distribution system. A control algorithm based on correlation and cross correlation function has been found suitable for generating the switching signals of DSTATCOM in a three phase system. The performance of DSTATCOM has been demonstrated for harmonic elimination, reactive power compensation and load balancing for variety of loads in PFC and ZVR modes of operation. The performance of DSTATCOM has been found satisfactory under varying load conditions. For estimation of active and reactive power components of load currents only numerical integration is used so it has been found simple and accurate compared to others control algorithms. The DC bus voltage of the DSTATCOM has also been regulated without much overshoot to desired value under varying load conditions.

\section{Nomenclature}

$\begin{array}{ll}\text { AC } & \text { Alternating current } \\ \text { DC } & \text { Direct current } \\ \text { Eq. } & \text { Equation } \\ \text { PCC } & \text { Point of common coupling } \\ \text { R } & \text { Resistance } \\ \text { L } & \text { Inductance } \\ \text { C } & \text { Capacitance } \\ \text { m } & \text { Mille } \\ \text { s } & \text { Time in second } \\ \text { THD } & \text { Total Harmonic Distortion } \\ \|\| & \text { Norm } \\ \alpha & \text { Firing angle of control rectifier } \\ \int & \text { Integration } \\ \phi & \text { Phase angle } \\ \% & \text { Percentage }\end{array}$

\section{Appendix}

AC supply source: 3 -phase, $415 \mathrm{~V}$ (L-L), $50 \mathrm{~Hz}$; Source Impedance: $\mathrm{R}_{\mathrm{s}}=0.04 \Omega, \mathrm{L}_{\mathrm{s}}=0.5 \mathrm{mH}$; Load: (1) Linear: $35 \mathrm{kVA}$, 0.8 p.f. lagg. (2) Non-linear: (a)Three phase full bridge controlled rectifier, $\alpha=30^{\circ}$ with $R=8 \Omega$ and $L=100 \mathrm{mH}$, (b) Three phase full bridge uncontrolled rectifier with $\mathrm{R}=8 \Omega$ and $\mathrm{C}=180 \mu \mathrm{f}$; Ripple filter: $\mathrm{R}_{\mathrm{f}}=5 \Omega, \mathrm{C}_{\mathrm{f}}=5 \mu \mathrm{F}$; DC bus capacitance: $10000 \mu \mathrm{F}$; Reference DC bus voltage: $700 \mathrm{~V}$; Gains of PI controller for DC bus voltage: $\mathrm{K}_{\mathrm{pd}}=0.92, \mathrm{~K}_{\mathrm{id}}=0.108$; Gains of voltage PI controller: $\mathrm{K}_{\mathrm{pq}}=2.56, \mathrm{~K}_{\mathrm{iq}}$ $=4.22$; Switching frequency $\left(\mathrm{f}_{\mathrm{s}}\right)=10 \mathrm{kHz}$

\section{References}

Devaraju T., Veera Reddy V.C. and Vijaya Kumar M., 2010. Role of custom power devices in power quality enhancement: A review. International Journal of Engineering Science and Technology, vol. 2, no.8, pp. 3628-3634.

Fuchs Ewald F. and Mausoum Mohammad A. S., 2008. Power Quality in Power Systems and Electrical Machines, Elsevier Academic Press, London. 
Ghosh Arindam and Ledwich Gerard, 2009. Power Quality Enhancement using Custom Power Devices, Springer International Edition, Delhi.

Munoz Antonio Moreno, 2007. Power Quality:Mitigation Technologies in a Distributed Environment, Springer-Verlag, London. Padiyar K.R., 2008. FACTS Controllers in Power Transmission and Distribution, New Age International, New Delhi.

Rahmani Salem, Mendalek Nassar and Al-Haddad Kamal, 2010. Experimental design of a nonlinear control technique for threephase shunt active power filter, IEEE Transactions on Industrial Electronics, vol. 57, no. 10, pp. 3364-3375.

Sankaran C., 2001. Power Quality, CRC Press, New York.

Saxena D., Verma K.S. and Singh S.N., 2010. Power quality event classification: an overview and key issues, International Journal of Engineering, Science and Technology, vol. 2, no. 3, pp.186-199.

Sharma S. and Singh B., 2011. An enhanced phase locked loop technique for voltage and frequency control of stand-alone wind energy conversion system, Proc. of IEEE International Conference on Power Electronics, pp.1-6.

Singh G. K., 2009. Power system harmonics research: a survey, European Transactions on Electrical Power, vol.19, pp.151-172.

Singh B. and Kumar S., 2010. Modified power balance theory for control of DSTATCOM, Proc. of IEEE Joint International Conference Power Electronics, Drives and Energy Systems and Power India, pp.1-8.

Singh Bhim, Jayaprakash P and Kothari D.P., 2008. A three-phase four-wire DSTATCOM for power quality improvement, Journal of Power Electronics, vol.8, no.3, pp.259-26.

Singh Bhim and Solanki Jitendra, 2009. A comparison of control algorithms for DSTATCOM, IEEE Transactions on Industrial Electronics, vol.56, no.7, pp.2738-2745.

Tanaka Toshihiko, Hiraki Eiji, Ueda Kengo, Sato Kuniaki and Fukuma Shinji, 2007. A novel detection method of active and reactive currents in single phase circuits using the correlation and cross-correlation coefficients and its applications, IEEE Transactions on Power Delivery, vol.22, no.4, pp.2450-2456.

Tanaka T., Nishida Y. and Funabiki S., 2002. A novel method of compensating harmonic currents generated by consumer electronic equipment based on the correlation function, Proc. of IEEE Power Conversion Conference, Osaka, pp.172-177.

Tanaka Toshihiko, Fukui Hirokazu, Hiraki Eiji, Watanabe Shuuji and Fukuma Shinji, 2009. A new current balancer in singlephase three-wire secondary distribution feeders using the correlation coefficients, Journal of Electrical Engineering in Japan,vol.169,no.1, pp.675-681.

Teke Ahmet, Saribulut Lutfu, Meral M. Emin and Tumay Mehmet, 2011. Active power filter: review of converter topologies and control strategies, Journal of Science Gazi University, vol.24, no.2, pp.283-289.

Wetula Andrzej, 2008. A Hilbert transform based algorithm for detection of a complex envelope of a power grid signals an implementation, Journal of Electrical Power Quality and Utilisation, vol. 14, no. 2, pp.13-18.

Wu Longhui, Zhuo Fang and Wang Zhaoan, 2007. Soft phase locked loop for active power filter applied in small rating standalone power system, Proc. of IEEE Conference on Power Electronics Specialists, pp.2600-2606.

Zeng Jiang, Liu Yan, Ouyang Sen and Zhen Zaitian, 2010. Novel hysteresis current controller for active power filter, Proc. of IEEE Conference on Electrical and Control Engineering, pp.1378-1384.

\section{Biographical notes}

Bhim Singh received his B.E. in Electrical Engineering from the University of Roorkee, Roorkee, India, in 1977 and his M.Tech. and Ph.D. from the Indian Institute of Technology (IIT) Delhi, New Delhi, India, in 1979 and 1983, respectively. In 1983, he joined Department of Electrical Engineering, University of Roorkee, as a Lecturer, and in 1988 he became a Reader. In December 1990, he joined Department of Electrical Engineering, IIT Delhi, as an Assistant Professor. He became an Associate Professor in 1994 and a Professor in 1997. He has guided 38 Ph.D. dissertations, 120 M.E./M.Tech./M.S.(R) theses, and 60 BE/B.Tech. Projects. His areas of interest include power electronics, electrical machines and drives, renewable energy systems, active filters, FACTS, HVDC and power quality. Dr. Singh is a Fellow of the Indian National Academy of Engineering (INAE), the National Science Academy (NSc), the Institute of Electrical and Electronics Engineers (IEEE), the Institute of Engineering and Technology (IET), the Institution of Engineers (India) (IE(I)), and the Institution of Electronics and Telecommunication Engineers (IETE). He is also a life member of the Indian Society for Technical Education (ISTE), the System Society of India (SSI), and the National Institution of Quality and Reliability (NIQR). He received the Khosla Research Prize of the University of Roorkee in the year 1991. He was the recipient of J.C. Bose and Bimal K. Bose Awards of the Institution of Telecommunication Engineers (IETE) for his contributions in the field of power electronics in the year 2000. He was also a recipient of the Maharashtra State National Award of the Indian Society of Technical Education (ISTE) in recognition of his outstanding research work in the area of Power Quality in the year 2006. He received the PES Delhi Chapter Outstanding Engineer Award for the year 2006. He was the General Chair of the IEEE International Conference on Power Electronics, Drives and Energy Systems (PEDES'2006) and (PEDES'2010) held in New Delhi.

Sabha Raj Arya received his B.E. in Electrical Engineering from Government Engineering College Jabalpur, India, in 2002 and M.Tech. in Electrical Engineering with specialization in Power Electronics and ASIC Design from the Motilal National Institute of Technology, Allahabad, India in 2004. In July 2004, he joined Department of Electrical Engineering, Kalinga Institute of Industrial Technology (Deemed university) Bhubaneswar as a lecturer. In December 2006, he joined Department of Electrical Engineering, Sardar Vallabhbhai National Institute of Technology, Surat, as an Assistant Professor. He is currently at Department of Electrical Engineering, Indian Institute of Technology, Delhi, India, where he is pursuing towards $\mathrm{PhD}$ degree under Quality Improvement Programme. His fields of interest include power electronics, power quality and design of Custom power devices.

Received January 2012

Accepted February 2012

Final acceptance in revised from March 2012 